Юодищюс Мантас

магистрант

Уипурене Айсте Барбора

д-р пед. наук, преподаватель, лектор

Литовский университет спорта

г. Каунас, Литовская Республика

DOI $10.21661 / r-551747$

\title{
ACCESSIBILITY OF RURAL TOURISM SERVICES FOR THE DISABLED IN LITHUANIA
}

Аннотация: сельский туризм имеет большой потенциал для привлечения людей с разными интересами, однако он требует тесного сотрудничества при планировании и реализачии стратегических направлений развития и мер, связанных с туризмом. В настоящее время устанавливается социальная модель интеграции инвалидов. Для путешествий человеку с ограниченными возможностями требуется адаптированная инфраструктура. Действия должны предприниматься в соответствии с принципом, согласно которому люди с ограниченными возможностями, как и все люди, нуждаются в доступе и интеграции. Поэтому важно изучить доступность услуг сельского туризма для инвалидов в Литве.

Ключевые слова: сельский туризм, инвалидность, доступность услуг.

Abstract: rural tourism has great potential for attracting people with different interests, but it requires close cooperation in the planning and implementation of strategic development directions and measures related to tourism. At present time, the social model of integration of the disabled is becoming more and more established. A person with a disability needs adapted infrastructure to travel. Actions should be implemented in accordance with the principle that people with disabilities, like all people, need access and integration. Therefore, it is important to study the accessibility of rural tourism services for the disabled in Lithuania.

Keywords: rural tourism, disabled, services accessibility. 


\section{Introduction}

Rural tourism has great potential for attracting people with different interests, but it requires close cooperation in the planning and implementation of strategic development directions and measures related to tourism. Disability has existed since ancient times in all nations and communities. The well-being and quality of life of people with disabilities depend directly on the prevailing attitude in that society, as these people are often unable to fight directly for their own lives and lives, and depend on the help of others (Masedonskienè, 2008). At present time, the social model of integration of the disabled is becoming more and more established. Attention is beginning drawn to the fact that although treatment or rehabilitation are important areas, they are only a small part of the needs of people with disabilities. Their further integration into society depends on the adaptation and change of the environment, the creation of comprehensive conditions for independent living (Jokūbpreikšas, 2013). A person with a disability needs adapted infrastructure to travel. Actions should be implemented in accordance with the principle that people with disabilities, like all people, need access and integration. Therefore, it is important to study the accessibility of rural tourism services for the disabled in Lithuania.

\section{Results and Conclusions}

Rural tourism is a new type of tourism activity that emerged at the end of the 19th century and was actively developed after the Second World War. The theory that rural tourism originated in France is popular in current academic circles. Others argue that rural tourism originated in the UK in the late 19th century as a result of the industrial revolution that improved people's lives and gave them more rest. (Tang lu, 2017). Recreational conditions in Lithuania are favorable and allow to develop rural tourism business. According to the data of the Ministry of Agriculture of the Republic of Lithuania, Lithuania's recreational potential suitable for the development of rural tourism is extremely diverse - it consists of abundant forests, a dense network of inland waters, cultural heritage objects and traditional crafts. The resort's abundant medical and recreational resources can meet the huge needs for health services and resort development. 
Surviving castles, defensive heritage sites, churches and monasteries, manors and manor houses, historical parks, ethnographic villages and industrial heritage are important for tourism. (Žilinskas, Maksimenko, 2008). At present, the social model of integration of the disabled is becoming more and more established. Attention is beginning to be drawn to the fact that although treatment or rehabilitation are important areas, they are only a small part of the needs of people with disabilities. Their further integration into society depends on the adaptation and change of the environment, the creation of comprehensive conditions for independent living (Jokūbpreikšas, 2013). According to the program provided by the Government of the Republic of Lithuania, the aim is to create a harmonious environment and conditions for the effective development of social integration processes for the disabled in Lithuania and to ensure the implementation of national legislation.

After analyzing previous research in this field (Vichauskaitè, 2010; Jokūbpreikšas, 2013), it can be stated that in the field of Lithuanian rural tourism there is still a mismatch between the demand and supply of services, especially if it concerns people with mobility impairments. A study (Vichauskaitè, 2010) revealed that certain rural tourism homesteads, analyzing individual cases in a certain region, are not fully adapted for the disabled, homesteads offer few services to this tourism segment, and the disabled are not sufficiently informed about accommodation and leisure opportunities. Today, it is important to further investigations whether the situation has recently improved and rural tourism services in Lithuania have become accessible to people with physical disabilities.

\section{Список литературы}

1. Jokūbpreikšas L. Relationships between psychological reactions of adults with physical disabilities to their disability and social activity: master's thesis. -2013 .

2. Masedonskienè A. Problems of social activity and social image of people with disabilities: master's thesis -2008 .

3. Tang lu. The Overview of the Origin and Research of Rural Tourism Development. Advances in Intelligent Systems Research // 7th International Conference on Management, Education and Information (MEICI 2017). - 2017. - Vol. 156. - P. 448-452. 
4. Vichauskaite V. Opportunities for the development of tourism services for the disabled: master's thesis. -2010 .

5. Žilinskas V.J., Maksimenko M. Perspectives of sustainable development of rural tourism // Management science and studies. - 2008. - Vol. 13. 